\title{
A JUSTIÇA DO COMENDADOR (BAIXA PROVENÇA, SÉCULO XIII)
}

\section{LA JUSTICE DU COMMANDEUR (BASSE-PROVENCE, XIII ${ }^{\mathrm{e}}$ SIÉCLE)}

Damien CARRAZ ${ }^{* *}$

\section{RESUMO:}

As ordens militares, como senhores eclesiásticos, exerceram a justiça temporal sobre populações das quais elas estavam encarregadas. A historiografia, se ele se interessou pelos conflitos de jurisdição que opuseram os poderes soberanos às comendadorias, subestimou, salvo exceções, as atividades judiciárias destas últimas. Os ricos arquivos das ordens do Hospital e do Templo, no Midi Francês, fornecem belas séries de atas da prática judiciária clamores, inquéritos criminais, processos verbais de condenações... O caso dos dois senhorios templários de Lansac e de Montfrin e as comparações oferecidas pela importante jurisdição hospitalária de Manosque, recentemente e notavelmente estudada, autorizam uma contribuição sobre o papel dos irmãos guerreiros na difusão dos usos jurídicos e no controle social. O pessoal empregado no serviço destas pequenas justiças senhoriais, os procedimentos utilizados pela justiça criminal, a repressão da delinquência ordinária que assolava estes castra da Baixa Provença e, enfim, os limites opostos ao poder coercitivo do Templo pela organização das comunidades e pelo reforço do Estado foram sucessivamente evocados. $\mathrm{O}$ funcionamento, os ideais almejados, assim como a ação repressiva, pouco evidenciam a especificidade desta justiça da Igreja que não recusava o exercício do merum imperium e a aplicação das penas aflitivas. Centradas sobre o século XIII, período de transição na história do procedimento, estas primeiras observações desejariam ser prosseguidas para os dois séculos seguintes: a originalidade da justiça do Hospital, com a instauração de uma ordem moral, mais do que cívica, apareceria mais, tanto que seria necessário avaliar a resistência destes senhorios às reconquistas jurisdicionais do Estado principesco.

\section{PALAVRAS CHAVE:}

Justiça; Senhorio; Ordens Militares; Poder Soberano; Provença; Idade Média.

\footnotetext{
"Uma versão inaugural deste artigo foi publicado inicialmente nos Cahiers de Fanjeaux: CARRAZ, Damien. La justice du commandeur (Bas-Rhône, XIII ${ }^{\mathrm{e}}$ siècle). In: Cahiers de Fanjeaux, $\mathrm{n}^{\circ}$. 42. Les justices d'Église dans le Midi (XI ${ }^{\mathrm{e}}-\mathrm{XV}^{\mathrm{e}}$ siècle). Toulouse: Privat, 2007, p. 243-268. Desde 2007, poucos trabalhos foram consagrados especificamente ao exercício da justiça pelas ordens militares. Para uma apreciação sintética da questão, o leitor poderá se reportar a CARRAZ, Damien. Droit e Justice. In: JOSSERAND, Ph. (dir.) \& BÉRIOU, N. (dir.). Prier et combattre. Dictionnaire européen des ordres militaires au Moyen Âge. Paris: Fayard, 2009, p. 309-311 e 517520. À escala da Provença, o importante senhorio do Hospital de Manosque continuou a alimentar reflexões. Ver, notadamente: BORCHARDT, K.; CARRAZ, D. \& VENTURINI, A. Édition des comptes hebdomadaires de la commanderie de l'Hôpital de Manosque pour les années 1283 à 1290. Paris: Edições CNRS (no prelo) e, sobretudo: BEDNARSKI, S. Curia: A Social History of a Provençal Criminal Court in the Fourteenth Century. Montpellier: PULM, 2013. Para situar o exercício da justiça pelas comendadorias provençais na história mais ampla da dominação senhorial, ver: VERDON, L. La Voix des dominés: Communautés et seigneurie en Provence au bas Moyen Âge. Rennes: PUR, 2012. Agradeço a Bruno Tadeu Salles por sua tradução do francês.

${ }^{* *}$ Maître de conférences Université Blaise Pascal - Clermont-Ferrand 2 (Clermont/França). E-mail: damien.carraz@wanadoo.fr
} 


\section{ABSTRACT:}

The military orders, as ecclesiastical gentlemen, exercised the temporal justice over populations which they were in charge of. The historiography, if he got interested about the jurisdiction conflicts that have opposed the sovereign powers to the commanderies, underestimated, with some few exceptions, the judicial activities of these last ones. The rich archives from the orders of the hospital and the temple, at the French Midi, provide beautiful series of the judicial practices - clamors, criminal investigations, verbal processes of condemnations... The case of the two templary landlords of Lansac and of Montfrin and the comparisons offered by the important hospitaller jurisdiction of Manosque, recently and notably studied, authorize an contribution over the role of the warrior brothers on the difusion on the juridical uses and on the social control. The people who ar e employed on the service of those small stately justices, the procedures used by the criminal justice, the repression of the ordinary delinquency that plagued those castra of the Low Provence and, ultimately, the limits opposed to the coercive power of the temple for the organization of the communities and for the reinforcement of the state were successively evoked. The operation, the desired ideals, just like the repressive action, do not show at all the specificity of the church's justice which wouldn't refuse the exercise of merum imperium and the application of the afflictive feathers. Centered over the 13th century, period of transaction on the history of procedure, these first observations would desire to be pursued for the two following centuries: the originality of the hospital's justice, with the establishment of a moral order, more than civic, would appear so much more that it would be necessary to evaluate the resistance of tho se landlords to the court re-conquests of the princely State.

\section{KEY-WORDS:}

Justice; Lordship; Military Orders; Sovereign Power; Provence; Middle Ages.

\section{INTRODUÇÃO}

No Midi da França, as ordens militares do Templo e do Hospital constituíram importantes senhorios fundiários. Esta posse do solo foi acompanhada de uma dominação sobre os homens, pois as comendadorias administraram paróquias e, sobretudo, herdaram poderes de justiça. A instar das justiças episcopais, estudadas por Thierry Pécout (2005: 383402), estes poderes foram pouco exercidos no quadro urbano, salvo quando as ordens possuíam inteiramente a dominação senhorial como em Manosque (para o Hospital) ou em Biot (para o Templo). Em compensação, estes religiosos exerceram um poder de coerção sobre numerosas comunidades rurais, mais frequentemente como detentores de todo ou parte do senhorio de uma vila, ou melhor, em virtude dos laços de submissão que tocavam certas categorias de dependentes.

Se a historiografia das ordens militares começou a se interessar pelo lugar dos juristas e pela difusão da cultura jurídica no seio destas instituições, ela tem, contudo, 


\section{A JUSTIÇA DO COMENDADOR (BAIXA PROVENÇA, SÉCULO XIII)}

abandonado amplamente o exercício da justiça propriamente dito (LUTTRELL, 1965; BRUNDAGE, 1994; JOSSERAND, 2004, p. 127-133) ${ }^{1}$. No melhor dos casos, este tema foi abordado pelo viés dos inevitáveis conflitos de jurisdição que opuseram as milícias aos poderes soberanos, notadamente na Península Ibérica, onde as relações entre as ordens e as monarquias foram particularmente escrutadas (FOREY, 1973, p. 130-133; AYALA MARTINEZ, 2003, p. 653-658 e JOSSERAND, 2004, p. 488-494) ${ }^{2}$. Quem trabalha com os arquivos meridionais do Templo e do Hospital não pode, entrementes, deixar de notar a atividade judiciária desenvolvida pelas ordens. Em Provença e no Languedoc, os arquivos de muitas comendadorias guardam traços do poder coercitivo destes senhorios monásticos ${ }^{3}$.

O excepcional fundo da importante corte hospitalária de Manosque deu lugar a fecundas pesquisas, vindas, sobretudo, do Canadá, acerca da sociedade, da criminalidade e das mentalidades ${ }^{4}$. Mas somente a tese de Patrícia Mac Caughan (2005) sobre La justice à Manosque au XIII siècle leu estes arquivos sob o ângulo da história do procedimento ${ }^{5}$. Este trabalho, se não aponta a especificidade do poder de justiça do Hospital no seio das justiças da Igreja, oferece um ponto de comparação essencial. De minha parte, eu me deterei principalmente em dois senhorios templários do vale baixo do rio Rhône: aqueles de Lansac e de Montfrin ${ }^{6}$. O primeiro destes castra dependia do bailio d'Autevès, próximo de Tarascon, $\mathrm{o}$ outro, desde meados do século XIII, recebeu um bailio submetido ao senescal de Beaucaire; logo, um está no condado de Provença, o outro se encontra, desde 1229, no reio de França. Aqui, como em outros lugares, é a transferência dos direitos senhorias de seus antigos detentores aristocráticos para o Templo que explica que este último garanta a conservação da ordem $^{7}$. A elaboração do perfil destas pequenas cortes da Igreja se apoia sobre dois tipos e fontes:

- os processos-verbais de julgamentos e de inquéritos criminais, cujo mais antigo em Lansac remonta a 1262 ou dezenove anos após o primeiro registro manosquino;

- os inquéritos conduzidos durante os conflitos jurisdicionais com as cortes reais angevina e capetíngia que esclarecem bem o funcionamento da justiça templária.

Mesmo que a distinção entre justiça criminal e civil nem sempre aparecesse bem estabelecida junto ao pessoal judiciário das comendadorias ${ }^{8}$, a documentação conservou mais os assuntos relevando da alta do que da baixa justiça ${ }^{9}$.

Após uma evocação do pessoal destas pequenas cortes da Igreja, buscar-se-á mostrar a tecnicidade de seus juízes através dos procedimentos utilizados nos processos criminais. Este quadro sucinto da criminalidade ordinária que assolava estas vilas occitans 
permite, principalmente, vislumbrar os diferentes modos de repressão utilizados pelos senhores eclesiásticos. A partir do último terço do século XIII, todavia, este sistema coercitivo se encontrou submetido ao controle crescente das comunidades rurais (communautés d'habitants) e, sobretudo, do Estado real.

\section{OS QUADROS DA PRÁTICA JUDICIÁRIA}

Acostumou-se insistir no desinteresse dos templários quanto aos estudos jurídicos: uma ilustração gritante disso seria a incapacidade para organizar sua defesa quando do processo (BRUNDAGE, 1994, p. 351-352; LUTTRELL, 2000, p. 142) ${ }^{10}$. Os hospitalários, quanto a eles, começaram a se aproximar do direito canônico desde meados do século XIII, especialmente em Paris. No século seguinte, a ordem contava, consequentemente, com muitos graduados em direito (LUTTRELL, 1965). No Midi Francês, a imersão das duas ordens no universo jurídico parece mais precoce ainda (CARRAZ, 2005, p. 370-383). Desde meados do século XII, a intensidade das atividades econômicas, o cuidado dedicado à gestão e à defesa dos direitos e o enraizamento urbano fizeram das comendadorias os clientes regulares para os notários e os jurisperiti. Também, não é surpreendente que as cartas redigidas para os irmãos servissem, na prática, como vetor privilegiado de transmissão do direito erudito. Esta já antiga familiaridade com o mundo do direito explica que, nos anos 1230, quando apareciam os primeiros testemunhos da atividade judiciária das comendadorias, o funcionamento destas cortes eclesiásticas já era bem consolidado. Ele repousava, notadamente, sobre um pessoal pouco numeroso, mas qualificado.

O poder judiciário era, inicialmente, encarnado pelo comendador. Em Montfrin, ele recebia as reclamações em nome do tribunal e pronunciava, às vezes, as sentenças ${ }^{11}$. Era na comendadoria que se dava o espetáculo judiciário. Em Manosque, após serem exercidas nos lugares públicos, tais como a praça ou o cemitério, a justiça investia sobre o palácio herdado dos condes de Forcalquier (REYNAUD,1981, p. 144). O mesmo vale para Montfrin, onde os procedimentos aconteciam, às vezes, na camera do comendador ou na capela, mas, sobretudo, na grande aula pintada do palácio templário ${ }^{12}$. O comendador delegava, todavia, o exercício da justiça a um bailio que procedia às detenções, inculpava os suspeitos no tribunal e fazia redigir as sentenças do juiz ${ }^{13}$. Encarnação do poder de coerção senhorial após o comendador, o bailio era assistido por banniers que eram recrutados entre os homens da vila. Às vezes, de temperamento belicoso, em todo caso, encarregados das tarefas menores, como a R. Fac. Dir. UFG, v. 39, n.1, p. 53 - 75, jan. /jun. 2015 


\section{A JUSTIÇA DO COMENDADOR (BAIXA PROVENÇA, SÉCULO XIII)}

execução das penas de fustigação, estes homens podiam suscitar a animosidade da população $^{14}$. Frequentemente, eles exerciam também a função de arautos. Os clamores, que faziam conhecer a norma imposta pelo poder senhorial e permitiam convocar suspeitos e testemunhas em justiça, eram, em seguida, registrados por um notário. Sua frequência, revelada por muitos testemunhos, participava da publicidade do poder senhorial e de sua ancoragem territorial $^{15}$.

A máquina judiciária fazia, doravante, apelo a técnicos. $\mathrm{O}$ recurso à redação de processos-verbais em todas as etapas do procedimento, a condução dos inquéritos e o desenvolvimento da apelação tornavam indispensável a vinculação especial de um escrivão. A necessidade de especialistas da escritura podia suscitar nestes castra, próximos das vilas onde irradiavam os estudos jurídicos, a emergência de dinastias de notários e de homens de lei ligados ao serviço dos senhorios templários ${ }^{16}$. O personagem central era, naturalmente, o juiz. Ligado o tempo todo ao tribunal do Templo, ele tinha obrigação de residência durante a duração de seu cargo ${ }^{17}$. Ele não deveria ser originário da jurisdição de seu exercício, contudo, este princípio conheceu distorções ${ }^{18}$. Em Montfrin, a ascensão de uma velha família local, os Montauros, permitiu a um de seus membros se tornar juiz do Templo entre 1295 e $1308^{19}$. O caráter anual do cargo, exigido ao pessoal da corte real e àqueles de Manosque, não parece ter sido verdadeiramente respeitado (GIORDANENGO, 2005, p. 115). O juiz Bertran de Luperiis, qualificado de juris civile professor e de legum doctor, era igualmente assinalado de modo descontínuo em Lansac entre 1294 e 1307. Uma prosopografia dos praticantes atestados em Provença foi esboçada para o século XIV, mas ela ainda deve ser feita para o século precedente (COULET, 1991, 311-328; BONNAUD, 2005, p. 233-248). Ela nos mostraria, sem dúvida, que os juízes empregados pelas comendadorias circulavam entre os tribunais condais e aqueles das outras pequenas jurisdições senhoriais. Em Lansac, estes jurisperiti ainda eram recrutados localmente e alguns deles foram igualmente empregados pela corte de Tarascon em outros momentos de sua carreira (CARRAZ, 2005, p. 389). Estes praticantes a serviço das ordens militares certamente conheciam as técnicas eruditas: identificamos, por exemplo, que um dos raros fragmentos de tratado de procedimento conservado no ar cultural meridional provinha da comendadoria do Hospital de Échirolles (Isère) ${ }^{20}$.

Estes pequenos tribunais da Igreja funcionavam, portanto, com um número restrito de agentes, não mais que quatro ou cinco laicos, aos quais se juntavam alguns religiosos, principalmente, o comendador ou seu procurador. 
2. A JUSTIÇA DO TEMPLO: A ROTINA DO PROCEDIMENTO

As ordens militares souberam atrair os jurisperiti mais familiarizados com as novas técnicas procedimentais. Patricia Mac Caughan finamente evidenciou que o modelo inquisitório entrava em uso em Manosque entre os anos 1243 e 1247 (MAC CAUGHAN, 2005, p. 66-70). Portanto, foi em uma jurisdição do Hospital que se atestou a utilização mais precoce do novo procedimento em Provença. Os acasos da conservação documental e, notadamente, as lacunas das fontes procedimentais produzidas pela corte real convidam, talvez, a nuançar o avanço manosquino. Todavia, a formidável série de registros conservada por este senhorio tende bem a confirmar a eficácia da administração estabelecida pelo Hospital. Para os senhorios mais modestos de Montfrin ou de Lansac, as diversas etapas do procedimento são conservadas em pedaços de pergaminho ${ }^{21}$. Mas, por demanda dos templários ou de seus sucessores hospitalários, muitas cópias notariadas foram realizadas a partir de registros desaparecidos, para serem, desde então, apresentados nos conflitos com a corte real $^{22}$. As diversas etapas do procedimento - inquéritos, processos-verbais de condenações detalhando precisamente os delitos, enunciados de sentenças muito mais breves - são registradas à parte, o que permite raramente reconstituir o desenrolar dos processos.

No microcosmo das vilas, a suspeita de um delito era rapidamente veiculada pelo rumor público ou fama ${ }^{23}$. Então, o instrumento inquisitório permitia à autoridade senhorial se valer desta fama para lançar os processos ${ }^{24}$. No final do século XII, o papel da fama no controle social, no seio da comunidade aldeã, depreende-se bem das muitas pesquisas sobre o funcionamento da justiça templária. Em Lansac, assim como em Montfrin, a atenção dedicada pelos pesquisadores à definição da fama e da vox publica pelas testemunhas mostra o quanto ela se encontrava, desde então, no coração do processo judiciário ${ }^{25}$. Os habitantes definiam corretamente a fama como a reputação de alguém, mas tinham dificuldade em estabelecer sua diferença da vox publica. A assimilação que alguns ainda faziam entre fama e justicia parece testemunhar bem a entrada nos costumes desta forma de encaminhamento ${ }^{26}$. Aquilo confirma, sem dúvida, que, ao curso do século do século XII, o controle senhorial aumentou sobre a população.

Com a ação de ofício, todavia, cabia à corte apresentar a prova ou a confissão, e não mais à acusação. O inquérito conduzido pelo notário da corte era, doravante, recorrente nos assuntos criminais. Os depoimentos das testemunhas eram registrados para servir ao julgamento, mas seu interrogatório poderia acontecer na presença do acusado, quando compareciam à audiência ${ }^{27}$. Os suspeitos eram convocados pelo arauto público para se R. Fac. Dir. UFG, v. 39, n.1, p. 53 - 75, jan. / jun. 2015 


\section{A JUSTIÇA DO COMENDADOR (BAIXA PROVENÇA, SÉCULO XIII)}

explicarem diante da corte templária em um prazo de dez dias, sob a pena de dez libras de multa $^{28}$. A melhoria das técnicas de comunicação, de registro e de controle senhorial permitia, quando o acusado não se apresentava, de impor a pena por contumácia ${ }^{29}$.

Se ele sempre era submetido a algum ritual - o previsto era "requisitus per sacramentum" tanto que o testemunho era simplesmente "testis juratus requisitus" -, o procedimento de inquérito afinava-se no último terço do século XIII. O testemunho era anotado no estilo indireto, salvo quando se transcrevia os diálogos entre os protagonistas, frequentemente floridos de injúrias ${ }^{30}$. Os interrogatórios eram enquadrados por uma lista, cada vez mais precisa, de artigos e buscava-se definir a origem do testemunho - o boato, o presenciar... - sondando a memória da testemunha ${ }^{31}$. Os inquéritos de jurisdição mostram que a prova testemunhal ainda era mais importante do que a prova escrita. Mas, o desenvolvimento da administração provocou a consideração da presença ou da ausência de testemunhos escritos ${ }^{32}$.

Em 1293, em um processo de jurisdição contra a corte real de Vallabrègues, o comendador de Montfrin distinguia os diferentes modos de desencadeamento dos processos: acusação, denúncia e outro modo excepcional ou inquérito de ofício ${ }^{33}$. O advento do modo inquisitório não provocou o desaparecimento do velho procedimento acusatório que podia ser desencadeado a partir de uma reclamação ${ }^{34}$. Neste caso, o interrogatório sucessivo do reclamante e do acusado trazia ainda as marcas do debate judiciário ${ }^{35}$. Mas o procedimento não era sem constrangimentos para o denunciador que devia atestar sua boa fé, contra a obrigação de seus bens, e prometer permanecer à disposição da justiça ${ }^{36}$. A cronologia da passagem do acusatório ao inquisitório pode ser estabelecida tão precisamente apenas em Manosque. A partir do último terço do século XII, a fórmula que abria quase todos os processos verbais - "pervenit ad audienciam curie domus Templi" - sugere o primado da denúncia ou da reclamação. Mas, como em Manosque, desde os anos 1247-1250, a denúncia estava bem integrada ao procedimento inquisitório, pois era a corte que sustentava a acusação (MAC CAUGHAN, 1998, p. 584-585). Este sistema híbrido tinha o mérito de implicar os habitantes no controle coletivo dos costumes e, ainda, de fazê-los atores da justiça.

Qualquer que fosse o procedimento, ao acusado era reconhecido o direito de se defender, mesmo se esta etapa da acusação judiciária aparecesse bem pouco na documentação. Após a acusação, um prazo de oito dias era habitualmente deixado para preparar a defesa. O prevenido poderia se apresentar com um defensor, procurador ou fiador e 
era convidado a ouvir ou a ler os testemunhos reunidos contra $\mathrm{ele}^{37}$. Desde 1250, a argumentação defensiva, que podia ser técnica, sugere que certos acusados recorriam a defensores qualificados, mesmo se sua intervenção aparecesse muito raramente nos processos-verbais dos escrivães ${ }^{38}$.

Os prazos judiciários não são fáceis de apreender, pois raramente se dispõem de todas as fases do procedimento. Para os pequenos assuntos de roubo ou de rixa, o prazo entre duas semanas e seis meses separava o encaminhamento do assunto e a sentença. Todavia, é evidente que a sistematização do apelo aumentou os prazos, contrariando a ideia, que prevaleceu por muito tempo, de que a ordem pública exigia uma repressão exemplar e imediata (GRAND, 1941, p. 51-108).

\section{CRIMES E CASTIGOS.}

Em Lansac, os templários exerciam a alta e a baixa justiça ${ }^{39}$. A documentação disposta cobre uma quarentena de anos - 1267-1307 - de exercício da corte e conserva a lembrança de cerca de sessenta questões. Uma parte (vinte e três questões) se aplicava a pequenos furtos que diziam respeito frequentemente a animais de criação, alimentos ou vestimentas. Estes roubos, bem característicos de um meio rural, sugerem a precariedade de uma parte da população ${ }^{40}$. Em seguida, vinham as rixas e as violências de toda natureza (dezoito caos). Os comportamentos normalmente injuriosos, em que se podia ferir até a effusio sanguinis, são próprios desta sociedade da honra (GAUVARD, 1991, 705-752) ${ }^{41}$. Em Manosque, na mesma época, $80 \%$ das questões conservadas pelos arquivos judiciários do

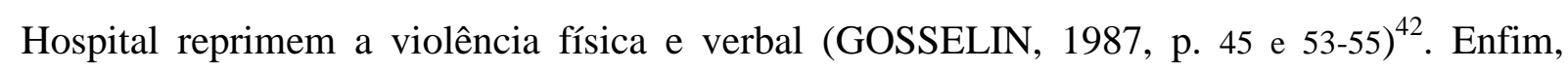
aparecem os casos de costumes que concernem principalmente à frequentação de prostitutas (seis casos). Em Montfrin, os conflitos de sociabilidade revelam atitudes mentais similares: feria-se habitualmente, até deflagrar verdadeiras guerrilhas com os homens dos vilarejos vizinhos $^{43}$, roubava-se, violava-se, enganava-se seu cônjuge. A noite era favorável às transgressões, frequentemente cometidas após as vésperas ou "entre cão e lobo" ("inter canem et lupum") ${ }^{44}$. Deste lado do Rhône, todavia, a implantação do rei de França retirou definitivamente dos templários o direito de dirimir os casos de homicídio e de traição ${ }^{45}$. Este quadro sucinto da criminalidade nestes senhorios da Igreja é, acima de tudo, bem banal: dois séculos mais tarde, o registro da jurisdição da antiga comendadoria do Templo de Paris, estudado entre os anos 1411-1412, reprimia, antes de tudo, as dívidas não pagas, os roubos, as 


\section{A JUSTIÇA DO COMENDADOR (BAIXA PROVENÇA, SÉCULO XIII)}

injúrias que degeneravam em brigas e alguns assuntos de costumes (ÉTIENNE, 1987, p. 329$330)$.

Diferentemente de certos senhorios monásticos, as ordens militares não repugnaram exercer a alta justiça e a aplicar penas corporais ${ }^{46}$. Nas comendadorias do Baixo Rhône, a fustigação - com ou sem efusão de sangue - era de longe a mais praticada. A marca de ferro em brasa, sobre a fronte, se revestia de um caráter excepcional em caso de roubo agravado ou de reincidência. Eu não tenho assinalado casos de amputação de membros, mas os estatutos de Manosque, editados pelo Hospital em 1235, previam a aplicação desta pena em numerosos casos - incêndio voluntário, ameaça com arma, roubo noturno com arrombamento, violação de uma mulher casada, etc. (ISNARD, 1894, p. 54-64, nº XIV) ${ }^{47}$. Em outras comendadorias, ainda são atestados alguns casos de execuções capitais por enforcamento - Templo de Jalès, Hospital de Saint-Maurice-de-Cazevieille, tanto que, em Sainte-Eulalie de Larzac (Templo), o homicídio habitualmente podia ser sancionado por um sepultamento vivo ${ }^{48}$. A frequência da pena capital é, todavia, impossível de avaliar na ausência de fontes seriadas. A prisão, enfim, era utilizada, principalmente, para prender os suspeitos antes de seu julgamento. Ela aparece pouco como solução repressiva, mesmo se as condições de detenção pudessem ser duras às vezes ${ }^{49}$. No total, as penas aflitivas, reservadas talvez aos indivíduos insolventes, pareciam ser relativamente pouco frequentes: em 1289, uma inquirição sugere que, em trinta anos, os habitantes de Lansac não assistiram a mais de três flagelações sobre o patíbulo, mas ela revela a frequência das multas ${ }^{50}$.

O estado religioso das ordens militares as conduzia a moderar os castigos corporais? Os estatutos de Manosque, aos quais frequentemente os juízes se referiam explicitamente, aplicavam as mesmas penas que em outras jurisdições e não mostravam qualquer repugnância particular quanto à violência. Entretanto, Rodrigue Lavoie (1979, p. 15 e 18-19) acredita discernir, neste senhorio, um nítido horror ao sangue e uma sensibilidade quanto aos problemas sociais e humanos que ele associou à vocação caritativa do Hospital. Para o período entre 1289-1300, as penas aflitivas representavam, de fato, somente entre 2 a $4 \%$ de um total de quinhentas condenações ${ }^{51}$. No Baixo Rhône, as inquirições de jurisdição destacavam a intransigência da justiça senhorial laica contrastada às práticas judiciárias do Templo (CARRAZ, 2005, p. 391-392). Contudo, por serem raros, os suplícios físicos não menos conservavam um valor altamente exemplar. Em Montfrin, a fustigação era itinerante e seu caminho passava por todos os lugares de destaque da vila: a porta, a rua principal, a igreja e a praça. O condenado era precedido por um arauto que convidava os habitantes ao 
espetáculo, anunciando o delito ${ }^{52}$. O ritual judiciário não devia ser apenas dissuasivo, também devia ser infamante (GAUVARD, 2005, p. 67). Os instrumentos repressivos eram exibidos, como o pelourinho na praça da vila ou as forcas patibulares situadas na junção de muitas $\operatorname{rotas}^{53}$. Tudo concorria, então, para a publicidade do "teatro judiciário" (CHIFFOLEAU, 1984): a praça pública acolhia a cerimônia de entrada em função do juiz, sob os auspícios do comendador $^{54}$. Ela era, também, o lugar onde as condenações eram proclamadas ${ }^{55}$.

As penas pecuniárias eram então privilegiadas: elas sancionavam os dois terços dos delitos em Lansac. Aquelas se estendiam de 100 soldos a alguns denários segundo a gravidade da falta. Certa clemência se manifestava, todavia, por uma redução das multas por diferentes motivos: pobreza, juventude, caráter espontâneo das confissões, fato de ser novo na vila e, então, não conhecer ainda todas as regras, tempo já passado em detenção, legítima defesa $^{56}$. Estes múltiplos casos de "penas mitigadas" sugerem certa liberdade dada ao arbítrio do juiz, que não mais se limitava exclusivamente às tarifas costumeiras para estabelecer as penas $^{57}$. A multa era frequentemente combinada com a velha composição revertida às vítimas em reparação dos prejuízos ${ }^{58}$. O caráter de compromisso da justiça se manifestava igualmente pelo fato de que os culpados podiam antecipar a sentença oferecendo uma composição à corte. Trata-se de um meio legal de interromper o processo e, então, salvar sua honra ${ }^{59}$.

A nítida predileção pelas multas, em detrimento das punições corporais, mais terríveis, mas não lucrativas, demonstra que as comendadorias esperavam, antes de tudo, um proveito financeiro do poder de justiça. A justiça do comendador era então rentável? É impossível saber qual a proporção das multas, pagas em um prazo de dez dias, verdadeiramente embolsada. Para os graves delitos, a detenção, até o pagamento, era um meio de pressão ${ }^{60}$. Mas pode-se, sem dúvida, interpretar, como uma confissão de fraqueza, os numerosos casos de redução de pena, explicados, sobretudo, pela insolvabilidade dos culpados. É difícil mencionar as cifras, mesmo quando apareceram preocupações contábeis no século XIV. Deduzir-se-á, sobretudo, que a rentabilidade da justiça podia variar muito de uma dominação a outra ${ }^{61}$. Em 1313, na importante comendadoria templária de Ruou (Var), entregue há pouco tempo ao Hospital, os direitos de ban, a justiça e as leydes representavam $10 \%$ dos rendimentos do senhorio, tanto que em Lansac, em 1338, as multas representavam somente 0,4\% das receitas (SIGAL, 1986, p. 362; STOUFF, 1986, p. 362). Na lógica "de uma justiça fiscalizada ao extremo" (LAVOIE, 1979, p. 12-13), destacamos, sobretudo, a característica sistemática deste tipo de arrecadação, destinada a ancorar, nas consciências, a presença do poder senhorial. Se é difícil avaliar o quanto a justiça arrecadava, é ainda mais difícil estabelecer o quanto ela custava. Qual era o peso, nas receitas de uma comendadoria, R. Fac. Dir. UFG, v. 39, n.1, p. 53 - 75, jan. / jun. 2015 


\section{A JUSTIÇA DO COMENDADOR (BAIXA PROVENÇA, SÉCULO XIII)}

dos salários dos diversos empregados, mais ou menos qualificados, da manutenção de instrumentos de poder repressivo - prisão, enforcamentos... - da gestão dos arquivos

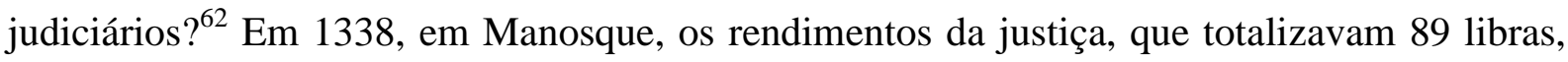
ultrapassavam pouco os diversos custos do pessoal, que se elevavam a 78 libras, aos quais era necessário acrescentar a alimentação ${ }^{63}$.

\begin{tabular}{|c|c|c|c|c|c|}
\hline \multicolumn{3}{|c|}{ Entradas } & \multicolumn{3}{|c|}{ Saídas } \\
\hline Manosque & $\begin{array}{l}l \\
\text { condempnaciones } \\
\text { lates (multas sobre } \\
\text { delitos relativos ao } \\
\text { polícia rural) } \\
\text { contumácias } \\
\text { criées (clamores ou } \\
\text { anúncios públicos } \\
\text { realizados pelos arautos } \\
\text { e registrados nos } \\
\text { estatutos municipais) }\end{array}$ & $\begin{array}{l}421 . \\
311.2 \mathrm{~s} . \\
21.10 \mathrm{~s} . \\
51 .\end{array}$ & \multirow[t]{2}{*}{ in natura } & $\begin{array}{lr}\text { nutrição } & \text { do } \\
\text { juiz, de um } \\
\text { escudeiro, de } \\
\text { um servidor e } \\
\text { de dois } \\
\text { notários. }\end{array}$ & 80 sétiers \\
\hline \multirow[t]{6}{*}{ Dependências } & \multirow[t]{6}{*}{$\begin{array}{l}\text { Volx: lates } \\
\text { Volx: condempnaciones } \\
\text { Montagut: jurisdição }\end{array}$} & \multirow[t]{6}{*}{$\begin{array}{l}11 . \\
21 . \\
6 \mathrm{~s} .\end{array}$} & & $\begin{array}{l}\text { vinho do juiz, } \\
\text { de um } \\
\text { escudeiro, de } \\
\text { um servidor }\end{array}$ & 300 cupas \\
\hline & & & \multirow{5}{*}{$\begin{array}{l}\text { Em } \\
\text { numerário }\end{array}$} & salário do juiz & 301. \\
\hline & & & & $\begin{array}{l}\text { companhia do } \\
\text { juiz, de um } \\
\text { escudeiro, de } \\
\text { um servidor }\end{array}$ & 41. \\
\hline & & & & $\begin{array}{l}\text { companhia dos } \\
\text { dois notários }\end{array}$ & 31. \\
\hline & & & & $\begin{array}{ll}\text { defesa } & \text { dos } \\
\text { direitos } & \\
\end{array}$ & $201 .+51$. \\
\hline & & & & advogados & $\begin{array}{l}161.13 \mathrm{~s} . \\
4 \mathrm{~d} .\end{array}$ \\
\hline $\begin{array}{l}\text { TOTAIS } \\
\text { (em numerário) }\end{array}$ & & & \multicolumn{3}{|c|}{781.13 s. 4 d. } \\
\hline
\end{tabular}

O orçamento da justiça em Manosque em 1338 (Fonte: BEAUCAGE, 1982, p. 333-361)

\section{LIMITES DO PODER DE JUSTIÇA}

A afirmação das comunidades rurais constituiu um primeiro limite ao exercício da justiça do comendador. Em 1237, em Lansac, três anos somente após a chegada dos templários, a universitas, pretendendo estar organizada há muito tempo em consulado, disputou com o novo senhor o exercício do merum et mixtum imperium ${ }^{64}$. A major dominatio 
foi confirmada ao Templo, que devia, entretanto, aceitar a existência de um consulado inteiramente responsável pelo policiamento rural e compartilhar com ele os rendimentos do ban. Em Montfrin, o consulado foi revestido de um papel consultivo, pois ele aprovava a escolha dos agentes senhoriais (CARRAZ, 2005, p. 364-365). Mesmo se as comendadorias vieram a limitar a autonomia destes consulados, seus prud'hommes se preocuparam em deter os possíveis abusos de uma repressão enquadrada doravante pela norma estatutária ${ }^{65}$. Mesmo em Manosque, onde o Hospital tinha obtido a abolição do consulado (1213), a comunidade, multiplicando as disputas, conseguiu obter concessões na passagem dos século XIII para o XIV: reativação dos estatutos de 1235 prevendo a consulta dos prud'hommes em certos assuntos, recrutamento exterior do juiz e do notário da corte e, em pouco tempo, a manutenção de um juiz das primeiras apelações (REYNAUD, 1981, p. 35-37; LAVOIE, 1987, p. 13; MAC CAUGHAN, 2005, p. 31-34 ). Enfim, no Baixo Rhône, as manifestações contestatórias não foram raras: agressões contra os banniers, às vezes, contra o comendador ou a retirada das forcas patibulares ${ }^{66}$.

A ameaça mais séria devia, contudo, vir dos poderes soberanos. A partir da entrada do condado de Toulouse (1229) e, posteriormente, do condado de Provença (1246) na órbita capetíngia, o Estado real empreendeu reconquistar as partes da justiça pública passadas, desde gerações, para as mãos dos poderosos locais ${ }^{67}$. Do leste provençal ao Baixo Languedoc, a documentação guarda traços dos repetidos conflitos que opuseram as comendadorias aos agentes reais. Retomemos o caso de Lansac. O último terço do século XIII foi marcado pelo recrudescimento dos litígios entre o Templo e a jurisdição condal instalada em Tarascon ${ }^{68}$. O tema dos casos reais, desenvolvidos desde Raimundo Berengário $\mathrm{V}$, forneceu um primeiro pretexto para reduzir a dominação templária, reivindicando o direito de decisão sobre os crimes ocorridos nas vias públicas, nos cemitérios e em outros lugares sagrados ${ }^{69}$. Foi, notadamente, em torno das noções de merum et mixtum imperium que os oficiais reais se esforçaram por contestar aos templários suas atribuições jurisdicionais ${ }^{70}$. As disputas de poder se cristalizaram igualmente em torno dos limites territoriais das jurisdições concorrentes. Em 1266, o comendador de Arles teve que exigir um inquérito na corte de Tarascon para confirmar os limites da área habitada da villa de Lansac ${ }^{71}$. O procedimento não tinha nada de extraordinário: comunidades rurais e senhorios procediam à verificação dos limites de seus respectivos territórios em um contexto de concorrência pelos direitos de uso. Mas, nas paisagens moventes do Baixo Rhône, frequentemente modeladas pela flutuação das águas, a perenidade das fronteiras jamais fora segura ${ }^{72}$. Em terra capetíngia, a intromissão dos oficiais reais se tornaram igualmente sistemáticas. Em Montfrin, os agentes do poder central atacaram R. Fac. Dir. UFG, v. 39, n.1, p. 53 - 75, jan. / jun. 2015 
a jurisdição templária, disputando com a comendadoria o direito de arbitrar sobre muitos $\operatorname{assuntos}^{73}$. Em Saint-Maurice de Cazevielle, o senescal de Beaucaire obteve do prior de SaintGilles um acordo, atribuindo ao rei a metade das altas e baixas justiças e reservando ao poder temporal a execução das penas de morte e de mutilação ${ }^{74}$. De Manosque a Montfrin, o poder real aproveitou ainda das diferenças entre as comunidades e seus senhores eclesiásticos para impor sua arbitragem ${ }^{75}$. Os malfeitores gozavam, desde longo tempo, da imbricação espacial das jurisdições, partindo para se colocar sob a proteção de dominações vizinhas ${ }^{76}$. Porém, a justiça soberana conseguiu se insinuar ainda mais na vida dos acusados, desenvolvendo o apelo. Desde 1270, Afonso de Poitiers estipulou que o poder condal poderia substituir o Hospital no caso de negligência no exercício da justiça e sistematizou os apelos às instâncias centrais $^{77}$. Em 1307, um acordo com Carlos II estabeleceu igualmente que, nos senhorios do Hospital, os apelos seriam reservados à ordem, mas os segundos apelos seriam remetidos à corte real $^{78}$. Estes conflitos se seguiram por todo século XIV e nada tinham de exclusivo para a região: no domino real, os Olim testemunharam, a partir dos anos 1260, o controle crescente exercido pelo parlamento sobre as prerrogativas jurisdicionais das duas ordens militares (CARBASSE, 2002, p. 21-25).

Em face destas repetidas ingerências, a estratégia de defesa das milícias foi bem estabelecida. Quando um comendador se estimava lesado no direito de decidir sobre uma causa, ele empregava, de início, um procedimento de apelo endereçado ao juiz real local que desembocava, em geral, em um inquérito. Mas, face ao zelo dos vigários ou juízes locais, os templários foram frequentemente constrangidos a apelar às instâncias superiores, senescal, procurador da corte real ou juiz mor ${ }^{79}$. Em sua queda de braços com a administração angevina, os irmãos fizeram intervir, como procuradores, juristas capazes de manipular as sutilezas do procedimento de inquérito ${ }^{80}$. Eles souberam, igualmente, aproveitar as dissensões que podiam afetar a hierarquia da corte soberana. Entre 1288 e 1292, no julgamento de um assunto banal de furto, marcado por muitas reviravoltas de apelos em contrainquéritos, os templários de Lansac souberam atrair a benevolência de Raimundo Roux de Comps, juiz dos segundos apelos que, por duas vezes, deu-lhes razão contra o procurador real, Gui de Tabia ${ }^{81}$. Se era necessário redigir um resumo preciso ao fim do século XIV, parece que as comendadorias não tinham resistido muito mal a empresa crescente da justiça soberana. Talvez, elas mesmas ganharam com sua consolidação, não hesitando em apelar à corte real face às contestações das comunidades rurais ${ }^{82}$. 
A gestão dos patrimônios e o exercício das dominações senhorias instaram as comendadorias meridionais a recorrerem, muito cedo, aos serviços de homens de lei. Esta proximidade de fato com o direito se inseria no movimento geral de difusão das práticas jurídicas em meio monástico (BOUREAU, 2001). A permeabilidade das ordens militares ao direito, teórico e prático, permanece, todavia, um campo de estudo pouco explorado. Entretanto, é notável que, na Provença do século XII, os formulários redescobertos do direito romano aparecessem, primeiramente, nas cartas redigidas pelas comendadorias, pois, no século seguinte, a transição procedimental do acusatório ao inquisitório estava particularmente bem esclarecida pelas fontes judiciárias destas mesmas ordens. O vanguardismo dos irmãos guerreiros, que compreenderam muito rápido o interesse de recrutar os melhores profissionais, é somente uma impressão ligada à conservação da documentação? Reconhecemos, em todo caso, a contribuição das comendadorias para o controle das populações e para a normalização dos modos. Favorecendo "la révolution médiévale de l'inquisitoire" (THÉRY, 2003, p. 119-147), os juízes empregados pelo Hospital e pelo Templo modificaram o alcance da justiça, que não mais sancionava, tão somente, as afetações dos interesses privados, mas que instituía, doravante, uma verdadeira ordem pública. No século XIII, nestes senhorios eclesiásticos, a justiça se insinuou no cotidiano dos habitantes que, em suas diferenças, não hesitavam recorrer ao juiz. O contraste é grande com a jurisdição hospitalária de Choisy-le-Temple, em Seine-et-Marne, onde, em pleno século XV, as arbitragens e composições privadas ainda tinham, amplamente, a preferência dos aldeões (CHAVAROT, 1992, p. 10-11) ${ }^{83}$. Estas nuances se deviam ao meio cultural ou a cronologia? Eis que pesa, em todo caso, a diversidade das práticas judiciárias nos senhorios das ordens militares: é óbvio que aquelas se conformavam aos usos locais e se remetiam à competência dos juízes que as empregavam.

A justiça do comendador em Provença revela, contudo, o particularismo? Às ordens militares, que empregavam, como os outros responsáveis pela justiça, penas aflitivas, não parecia, verdadeiramente, se aplicar o interdito canônico de verter sangue ${ }^{84}$. Em nossos castra do Baixo Rhône, o juiz do Templo pronunciava suas condenações tendo Deus diante de seus olhos, invocando a Trindade e os Evangelhos postos diante dele. Se conformando, assim, às decretais publicadas dede Inocêncio III e a certas ordines iudiciarii, seu julgamento aparece como um espelho da justiça divina ${ }^{85}$. A assimilação ao pecado da fornicação ou a da agressão contra o comendador e a influência do Diabo sobre certos delitos revelavam uma mistura do foro externo com foro interno? ${ }^{86}$ Certas confissões eram ainda feitas "timore Dei postposito" $"$. A atenção que os inquéritos e as listas de condenação dedicavam aos insultos, R. Fac. Dir. UFG, v. 39, n.1, p. 53 - 75, jan. /jun. 2015 


\section{A JUSTIÇA DO COMENDADOR (BAIXA PROVENÇA, SÉCULO XIII)}

frequentemente com conotação sexual, lembra ainda que as mudanças verbais constituíram um campo importante do controle judiciário ${ }^{88}$. Entretanto, se se retoma o caso manosquino, é, sobretudo, a partir do século XIV, que o discurso jurídico se tinge de uma mensagem moral com a sistematização da noção de pecado, tanto que aparecem as primeiras qualificações de bruxaria $^{89}$. Se o século XIII permanece então um momento chave nas transformações procedimentais, a abundância da documentação incita a sondar os ideais e as práticas do controle social em numerosas jurisdições detidas pelas comendadorias meridionais, remontando até a aurora dos tempos modernos. Sem dúvida, ver-se-á que estes senhorios eclesiásticos continuaram, mais do que nunca, a participar da construção da soberania e de um espaço público...

\section{SIGLAS E ABREVIAÇÕES}

ADBdR: arquivos departamentais de Bouches-du-Rhône.

CGH: DELAVILLE LE ROULX, J. Cartulaire général de l'ordre des Hospitaliers de Saint-Jean-de-Jérusalem (1100-1310). Paris, 4 vol.,1894-1906.

CTGard: cartas do Templo de Montfrin, editadas ou analisadas em: CARRAZ, D. Ordres militaires, croisades et sociétés méridionales: L'ordre du Temple dans la basse vallée du Rhône (1124-1312), tese de doutorado, Université Lumière-Lyon 2, 2003, vol. 3, p. 61-278.

CT.TLL: cartas do Templo de Lansac, editadas ou analisadas em: CARRAZ, D. ibid., p. 279317.

FONTES:

ADBdR: arquivos departamentais de Bouches-du-Rhône.

BEAUCAGE, B. Visites générales des commanderies de l'ordre des Hospitaliers dépendantes du Grand Prieuré de Saint-Gilles (1338). Aix-en-Provence: PUP, 1982.

DELAVILLE LE ROULX, J. Cartulaire général de l'ordre des Hospitaliers de SaintJean-de-Jérusalem (1100-1310). Paris, 4 vol.,1894-1906.

CARRAZ, D. Ordres militaires, croisades et sociétés méridionales: L'ordre du Temple dans la basse vallée du Rhône (1124-1312), thèse de doctorat, Université Lumière-Lyon 2, 2003, vol. 3, p. 61-278. 
ISNARD, M.-Z.. Livre des privilèges de Manosque. Cartulaire municipal latin-provençal (1169-1315). Digne-Paris, 1894.

TRABALHOS:

BARATIER, É. \& VILLARD, M. Répertoire de la série H. 56 H: Grand prieuré de SaintGilles des Hospitaliers de Saint-Jean de Jérusalem. Marseille: Archives Départamentales des Bouches-du-Rhône, 1966.

BEDNARSKI, S. Curia: A Social History of a Provençal Criminal Court in the Fourteenth Century. Montpellier: PULM, 2013.

BONNAUD, J.-L. L'implantation des juristes dans les petites et moyennes villes de Provence au XIV ${ }^{\mathrm{e}}$ siècle. In: BOYER, Jean-Paul (dir.); MAILLOUX, Anne (dir.) \& VERDON, Laure (dir.). La Justice Temporelle dans les Territoires Angevins. Roma: École Française de Rome, 2005, p. 233-248.

BORCHARDT, K; CARRAZ, D. \& VENTURINI, A. Édition des comptes hebdomadaires de la commanderie de l'Hôpital de Manosque pour les années 1283 à 1290. Paris: Éditions CNRS (no prelo).

BOUREAU, A. La loi du royaume. Les moines, le droit et la construction de la nation anglaise (XII ${ }^{\mathrm{e}}$-XIII ${ }^{\mathrm{e}}$ siècles). Paris: Les Belles Lettres, 2001.

BOUTOULLE, F. Les mutations de la justice et de ses représentations dans une juridiction seigneuriale du XIIIe siècle: Maccaughan (Patricia), La justice à Manosque au XIIIe siècle. Évolution et représentation, Paris, Honoré Champion, Société des Amis des Archives de France, collection «Histoire et Archives » $\mathrm{n}^{\circ}$. 5, 2005 (Comptes Rendus et Notes Brèves). In: Annales du Midi: revue archéologique, historique et philologique de la France méridionale, tome $118, \mathrm{n}^{\circ} .256$. Esquisse d'une comparaison entre Latium et Catalogne (Xe-XIe siècles), 2006, p. 593-596.

BRUNDAGE, J. The Lawyers of the Military Orders In: BARBER, M (dir.). The Military Orders: Fighting for the faith and caring for the sick. Aldershot: Ashgate, 1994, p. 346-357.

CARBASSE, J.-M. Histoire du droit pénal et de la justice criminelle, Paris: PUF, 2000.

Les commanderies: aspects juridiques et institutionnels. In: LUTTRELL, A. (dir.) \& PRESSOUYRE, L (dir.). La Commanderie, institution des ordres militaires dans l'Occident médiéval (Actes du premier colloque international du Conservatoire Templier et Hospitalier, Sainte-Eulalie de Cernon, 13-15 octobre 2000). Paris: CTHS, 2002, p. 19-27.

CARCENAC, A.-R. Les Templiers du Larzac. Nîmes: Lacour, 1994.

CARRAZ, D. Droit. In: JOSSERAND, Ph. (dir.) \& BÉRIOU, N. (dir.). Prier et combattre. Dictionnaire européen des ordres militaires au Moyen Âge. Paris: Fayard, 2009, p. 309-311. 
. Justice. In: JOSSERAND, Ph. (dir.) \& BÉRIOU, N. (dir.). Prier et

combattre. Dictionnaire européen des ordres militaires au Moyen Âge. Paris: Fayard, 2009, p. 517-520.

L'Ordre du Temple dans la Basse Vallée du Rhône (1124-1312):

Ordres Militaires, croisades et sociétés méridionales. Lyon: PUL, 2005.

CHARAGEAT, M. Les sentences de l'official à Saragosse au XV siècle. In: Cahiers de Fanjeaux, $n^{\circ}$. 42. Les justices d'Église dans le Midi $\left(\mathrm{XI}^{\mathrm{e}}-\mathrm{XV}^{\mathrm{e}}\right.$ siècle). Toulouse: Privat, 2007, p. $317-42$.

CHARNAY, A. Un registre de justice de la commanderie des Canabières, 1318-1321. Revue du Rouergue, $n^{\circ}$. 23, 1990, p. 483-494.

CHAVAROT, Marie-Claire. Le registre des causes civiles et criminelles de Ia justice de Choisy-le-Temple: 1475-1478. édité et commenté (préface de Jean Hilaire). Paris: Centre d'étude d'histoire juridique, 1992.

CHIFFOLEAU, J. Les justices du pape. Délinquance et criminalité dans la région d'Avignon au XIV ${ }^{\mathbf{e}}$ siècle. Paris: Publications de la Sorbonne, 1984.

“Ecclesia de occultis non iudicat"? L'Église, le secret, l'occulte du XII au XV ${ }^{\mathrm{e}}$ siècle. In: Il Segreto, Micrologus, $\mathrm{n}^{\mathrm{o}}$.14, 2006, p. 448-450.

COULET, N. Les juristes dans les villes de la Provence médiévale. In: Les sociétés urbaines en France méridionale et en Péninsule ibérique au Moyen Age (Actes du colloque de Pau, 1988), Paris: CNRS, 1991, p. 311-328.

DURBEC, J.-A. Les vieux bourgs de Provence: Biot. Histoire et géographie humaine. In: Annales de la Société scientifique et litteraire de Cannes. t. VII, 1935, p. 187-194.

ÉTIENNE, G. Une justice seigneuriale à Paris : les audiences du tribunal de la commanderie du Temple au temps des Hospitaliers. In: Les libertés au Moyen Âge, (Festival d'histoire de Montbrison, 1-5 octobre 1986). Montbrison, 1987, p. 319-335.

FIXOT, R. Trois commanderies de l'ordre de Saint-Jean de Jérusalem d'après les enquêtes pontificales de 1338 et 1373: Saint-Pierre-Avez, Claret et Gap-Embrun. Mémoire de maîtrise, Université de Provence, 1995.

FOREY, A. J. The Templars in the «Corona» de Aragon. Londres: Durham University Publications, 1973.

GAUVARD, C. "De Grace especial": Crime, État et société en France à la fin du Moyen Âge. Paris: Publications de la Sorbonne, 1991.

Violence et ordre public au Moyen Âge. Paris: Picard, 2005. 
GIORDANENGO, G. Statuts royaux et justice en Provence (1246-1309). In: BOYER, JeanPaul (dir.); MAILLOUX, Anne (dir.) \& VERDON, Laure (dir.). La Justice Temporelle dans les Territoires Angevins. Roma: École Française de Rome, 2005, p. 107-126.

GOSSELIN, R. Honneur et violence à Manosque (1240-1260). In: HÉBERT, M. (dir.). Vie privée et ordre public à la fin du Moyen-Âge. Études sur Manosque, la Provence et le Piémont (1250-1450). Aix-en-Provence: Université de Provence, 1987, p. 45-64.

GRAND, R. Justice criminelle, procédure et peines dans les villes aux XIII et $\mathrm{XIV}^{\mathrm{e}}$ siècles. In: Bibliothèque de l'École des chartes, t. 102, 1941, p. 51-108.

HÉBERT, M. Autour de la cavalcade: les relations entre le comte de Provence, les Hospitaliers et la communauté de Manosque (XIII ${ }^{\mathrm{e}}-\mathrm{XIV}^{\mathrm{e}}$ siècles). In: Vie privée et ordre public à la fin du Moyen-Âge. Études sur Manosque, la Provence et le Piémont (1250-1450). Aix-en-Provence: Université de Provence, 1987, p. 141-158.

La justice dans les comptes de clavaires: bilan historiographique et perspectives de recherche. In: BOYER, Jean-Paul (dir.); MAILLOUX, Anne (dir.) \& VERDON, Laure (dir.). La Justice Temporelle dans les Territoires Angevins. Rome: École Française de Rome, 2005, p. 205-220.

Voce preconia: note sur les criées publiques en Provence à la fin du Moyen Âge. In : MORNET, Elisabeth (dir.) \& MORENZONI, Franco (dir.). Milieux naturels, espaces sociaux. Études offertes à Robert Delort, Paris: Publications de la Sorbonne, 1997, p. 689-701.

JOSSERAND, Ph. Église et pouvoir dans la Péninsule ibérique. Les ordres militaires dans le royaume de Castille (1252-1369). Madrid: Casa de Velázquez, 2004.

LAVOIE, R. Les statistiques criminelles et le visage du justicier: justice royale et justice seigneuriale en Provence au Moyen Age. In: Provence Historique, t. 28, 1979, p. 3-20.

Justice, Morale et Sexualité à Manosque au XIIIe siècle. Vie privée et ordre public à la fin du Moyen-Âge. Études sur Manosque, la Provence et le Piémont (1250-1450). Aix-en-Provence: Université de Provence, 1987, p. 9-21.

LUTTRELL, A. Fourteenth-Century Hospitaller Lawyers. In: Traditio, nº. 21, 1965, p. 449456.

Templari ed ospitalieri: alcuni confronti. In: CERRINI, S. (dir.). I Templari: La Guerra è la Santità. Rimini: Il Cerchio iniziative editoriali, 2000, p. 143-145.

MAC CAUGHAN, P. La justice à Manosque au XIII ${ }^{\mathrm{e}}$ siècle. Évolution et représentation, Paris : Honoré Champion, 2005.

La procédure judiciaire à Manosque au milieu du XIII ${ }^{\mathrm{e}}$ siècle, témoin d'une transition. In: Revue historique de droit, $\mathrm{n}^{\circ} .76,1998$, p. 584-585. 
AYALA MARTINEZ, C. de. Las Órdenes militares hispánicas en la Edad Media (siglos XII-XV), Madrid: Marcial Pons Historia. 2003.

MAZEL, Florian. La noblesse provençale face à la justice souveraine (1245-1320): L'âge du pragmatisme. In: BOYER, Jean-Paul (dir.); MAILLOUX, Anne (dir.) \& VERDON, Laure (dir.). La Justice Temporelle dans les Territoires Angevins. Rome: École Française de Rome, 2005, p. 343-370.

PASCHEL, P. Note sur la procédure judiciaire au $\mathrm{XV}^{\mathrm{e}}$ siècle: La justice de Choisy-le-Temple (1475-1478). In: Revue historique de droit français et étranger, $n^{0}$. 74, 1996, p. 573-584.

PÉCOUT, T. Les justices temporelles des évêques de Provence du milieu du XIII ${ }^{\mathrm{e}}$ au début du XIV ${ }^{\mathrm{e}}$ siècle. In : BOYER, Jean-Paul (dir.) ; MAILLOUX, Anne (dir.) \& VERDON, Laure (dir.). La Justice Temporelle dans les Territoires Angevins. Rome: École Française de Rome, 2005, p. 383-402.

REYNAUD, F. La commanderie de l'Hôpital de Saint-Jean de Jérusalem, de Rhodes et de Malte à Manosque: XII ${ }^{\mathrm{e}}$ siècle - 1789. Gap: Société d'études des Hautes-Alpes, 1981.

SIGAL, P. Une seigneurie ecclésiastique en Provence orientale au Moyen âge: la commanderie de Ruou. In: Provence Historique, t. 15, 1965, p. 126-146.

STOUFF, L. Arles à la fin du Moyen Âge. Aix-en-Provence: PUP, 1986.

THÉRY, J. Fama: l'opinion publique comme preuve judiciaire. Aperçu de la révolution médiévale de l'inquisitoire (XII ${ }^{\mathrm{e}}-\mathrm{XIV}^{\mathrm{e}}$ siècle). In : LEMESLE, B. (dir). La Preuve en justice de l'Antiquité à nos jours. Rennes: PUR, 2003, p. 119-147.

VERDON, L. Justice comtale et justice seigneuriale en Provence au miroir des enquêtes: L'exemple de la baillie de Castellane entre 1278 et 1310. In: BOYER, Jean-Paul (dir.); MAILlOUX, Anne (dir.) \& VERDON, Laure (dir.). La Justice Temporelle dans les Territoires Angevins. Rome: École Française de Rome, 2005, p. 371-382.

La Voix des dominés: Communautés et seigneurie en Provence au bas Moyen Âge. Rennes: PUR, 2012.

- Patricia MACCAUGHAN, La justice à Manosque au XIIIe siècle. Évolution et représentation, Paris, Honoré Champion Éditeur, collection «Histoire et Archives », 2005, 355 pages, ISBN: 2-7453-1291-X (BIBLIOGRAPHIE). In: Provence Historique, t. 56, fasc. 224, 2006, p. 241-244.

\footnotetext{
${ }^{1}$ Existem somente algumas exceções a esta falta de interesse pelo funcionamento da justiça das comendadorias: G. Étienne (1987, p. 319-335), Marie-Claire Chavarot, (1992) e P. Paschel (1996, p. 573-584).

${ }^{2}$ Para exemplos extraídos dos arquivos que falam de Paris e das casas templárias de Larzac: J.-M. Carbasse (2002, p. 21-24).

${ }^{3}$ Procedimentos engajados contra os acusados das ordens ou os conflitos de jurisdição opondo estas últimas ao poder centra foram, a partir de meados do século XIII, retranscritos em pergaminho ou registrados em cadernos de papel. Cf. É. Baratier e M. Villard [1966, p. $34-38$ e 184 (Hospital de Manosque, séculos XIII-XVIII), 56 (Hospital de Solliès, séculos XIV-XVI), 71 e 174 (Hospital de Gap, séculos XIV-XVI), 83 e 208 (Hospital e R. Fac. Dir. UFG, v. 39, n.1, p. 53 - 75, jan. / jun. 2015

ISSN 0101-7187
} 
Templo de Jalès, séculos XIII-XIV), 157 (Priorado de Saint-Gilles, séculos XIII-XVIII), 161 (Hospital d'Aix, séculos XIII-XVIII), 170 (Hospital de Béziers, XIII-XV), 176-177 (Hospital de Gap-Francès, séculos XIIIXVII), 180, 188 e 209 (Hospital e Templo de Montfrin, séculos XIII-XVIII), 110 e 192 (Hospital de Puimoisson, séculos XIII-XVII), 194-196 (Hospital de Saint-Christol, séculos XIII-XVI), 207 (Templo de Lansac e de Bras, séculos XIII-XIV), 210 (Templo de Sainte-Eulalie, XIII) e 211 (Templo de Saint-Maurice, século XIII)].

4 A maior parte destes trabalhos é mencionada por M. Hébert (2005, p. 212, nota $\left.\mathrm{n}^{\circ} .20\right)$.

${ }^{5}$ Sobre esta tese, ver os registros de L. Verdon (2006, p. 241-244) e de F. Boutoulle (2006, p. 593-596). A tese de S. Bednarski (2013) trabalha a cronologia posterior àquela abordada no trabalho de Mac Caughan. Contudo, a análise de Bednarski se coloca mais no terreno da história social do que no do estudo procedimental.

${ }^{6}$ O Senhorio de Lansac localiza-se no departamento francês de Bouches-du-Rhône e aquele de Montfrin no Gard.

7 A vila de Lansac foi dada ao Templo em 1234 por Uc de Baux com todos os direitos senhoriais compreendendo as justiças civis e criminais: et omnia omnino jura in predicta villa et predictis pertinentiis nobis qualitercumque ex quacumque causa competentia in personis sive in rebus, in justiciis et firmanciis et judiciis civilibus et criminalibus et angariis et parangariis, taschis, quartis, censibus, decimis et laudimiis, pasqiis, piscationibus et venationibus et ceteris usaticis consuetis, ADBdR, 56 H 5186 (23 de novembro de 1234). O cosenhorio dos castra de Monfrin-Trévils e de Meynes foi herdado da dominação de Pons de Meynes em 1146. O conteúdo dos direitos transmitidos é, neste caso, menos preciso: dominationibus que ad ipsum castellum (de Medenis) pertinent (...) et dominationibus que ad ipsam villam de Trevils pertinent, CTGard, $\mathrm{n}^{\circ} .001$ (novembro de 1146).

${ }^{8}$ Nos mesmos registros de condenação, feitos menores, como a fabricação de queijo contrária às normas estatutárias, se colocam ao lado de assuntos muito mais graves relativos aos costumes, CT.TLL, ${ }^{\circ} .24$ (5 de março de 1298/9). O registro da justiça do Templo de Paris, ocorrido entre março de 1411 e Julho de 1420 , mistura igualmente processos civis e criminais (ÉTIENNE, 1987, p. 328).

${ }^{9}$ É, igualmente, o caso da maior parte das outras jurisdições do Comtat estudadas por Jacques Chiffoleau (1984). Em compensação, em Canabières (arredores de Millau), onde o Hospital somente tinha a baixa e a média justiças, o registro judiciário compilado em 1318-1321 conserva, principalmente, os assuntos relativos à polícia rural (Charnay, 1990, p. 483-494).

${ }^{10}$ Trata-se do processo iniciado contra os templários pelo rei Filipe IV, o Belo, em Outubro de 1307. A questão foi concluída em maio de 1312, quando o Papa Clemente V decretou a supressão da Ordem do Templo.

${ }^{11}$ CTGard, $\mathrm{n}^{\circ} .127$ (1285).

${ }^{12}$ Aposento do comendador: CTGard, $\mathrm{n}^{\circ} .119$; capela: $\mathrm{n}^{\circ} .123$; aula: $\mathrm{n}^{\circ \mathrm{s}} .120,125$ bis, 126.

${ }^{13}$ Exemplos de sua atividade em Lansac: CT.TLL, $\mathrm{n}^{\circ}$. 12 (testemunho de Jaufré de Vaillier, antigo bailio do Templo, 23 de janeiro - 10 de fevereiro de 1265/6), 24 (5 de março de 1298/9) e 28 (24 de agosto de 1307).

${ }^{14}$ Banniers agredidos em Montfrin: CTGard, $\mathrm{n}^{\circ} .119$ (19 de setembro de 1278) e 141 (19 de agosto de 1295).

${ }^{15}$ CT.TLL, ${ }^{\text {os }} .17$ (11 de junho de 1284), 20 (testemunho de Bertran Arnaud, 3-11 de janeiro de 1289/90) e 26 (15 de julho de 1300 e 21 de abril de 1301). Cf. M. Hébert (1997, p. 689-701).

${ }^{16}$ Como as famílias Lobas e Montauros em Montfrin (CARRAZ, 2005, p. 371)

${ }^{17}$ O juiz Bertran de Luperiis tinha uma casa em Lansac, CT.TLL, $n^{\circ}$. 24 ( 5 de março de 1298/9).

${ }^{18}$ Os estatutos de Manosque exigiam que o juiz fosse estrangeiro à comunidade e que seu cargo fosse anual e não renovavel antes um prazo de cinco anos [ISNARD, 1894, p. 3-6, n'. I (12 fevereiro de 1207) e p. 153-155, $\mathrm{n}^{\circ}$. XLVII (27 de julho de 1300)].

${ }^{19}$ CTGard, $\mathrm{n}^{\circ \mathrm{s}} .119$ (21 de março de1295), 126 (16 de maio - 5 de agosto de 1295), 141 (13 de maio de 1297) e 148 (18 de maio de 1308).

${ }^{20}$ ADBdR, 56 H 3453. Trata-se das três primeiras folhas da Summa super officio advocationis in foro Ecclesie de Bonaguido d'Arezzo (v. 1249) (GIORDANENGO, 2005, p. 108, nº. 8).

${ }^{21}$ Em 1308, os documentos concernindo às jurisdições de Lansac e de Méjanes foram cuidadosamente arquivados na comendadoria de Arles, assim como atesta o inventário redigido quando da detenção dos irmãos templários. ADBdR, B 433 (24 de janeiro em 1308).

${ }_{22}$ Por exemplo: Extracta est de cartulario dicte domus de nota dicti magistri Petri Lagerii, quondam notarii dicte curie, prout in nota continetur, nichil de ea addito vel detracto, CTGard, $\mathrm{n}^{\circ} .100$ (19 de setembro - 8 de dezembro de 1250). Em um conflito de jurisdição contra a corte real de Vallabrègues, o comendador de Montfrin exibiu especialmente quatro registros, CTGard, $\mathrm{n}^{\circ}$. 139 (19 de abril de 1293). Os arquivos da corte de Lansac foram, em grande parte, transmitidos por copias notariadas do século XIV

${ }^{23}$ Por exemplo, CT.TLL, ${ }^{\circ}$. 11 (23 de abril de 1262): dictus Huguo (...) audiverat dici tunc temporis et fama erat in tenemento Lanciaci quod oves furate erant in dicto tenemento.

${ }^{24}$ CT.TLL, $\mathrm{n}^{\circ} .14$ (30 de junho de 1267): Inquisitio facta ex officio Lanciaci super eo quod dicitur quod...

${ }^{25}$ CT.TLL, $n^{\circ} .20$ (3 - 11 de janeiro de 1289/90) e CTGard, $n^{\circ} .139$ (8 de abril -27 de maio de 1293). Finalmente, sobre a fama como virada jurídica e judiciária, ver: J. Théry (2003, p. 119-147). 


\section{A JUSTIÇA DO COMENDADOR (BAIXA PROVENÇA, SÉCULO XIII)}

${ }^{26}$ CT.TLL, ${ }^{\circ} .20$ (testemunho de Isnard Aberti): Requisitus quid est fama, dixit quod justicia. Requisitus de voce, dixit quod nescit.

${ }^{27}$ CTGard, $\mathrm{n}^{\circ} .125$ ter $(3-18$ de fevereiro de $1292 / 3)$.

${ }^{28}$ CTGard, $\mathrm{n}^{\circ} .085$ (fevereiro de 1243); CT.TLL, $\mathrm{n}^{\circ} .17$ (11 de junho de 1284).

${ }^{29}$ CT.TLL, ${ }^{\circ}{ }^{\circ} .17$ (janeiro de 1284/5) e 24 (5 de março de 1298/9).

${ }^{30}$ Quando uma declaração concordava com aquela de uma testemunha precedente, o escrivão se contentava de

“dixit idem" CT.TLL, $\mathrm{n}^{\circ} .14$ (30 de junho de 1267).

${ }^{31}$ CT.TLL, $\mathrm{n}^{\circ} .20$ (3-11 de janeiro de 1289/90).

${ }^{32}$ Em um conflito de jurisdição onde o Templo de Lansac acusava à corte de Tarascon de ter usurpado um caso, esta última se defendia apontando a ausência de qualquer traço do dito caso nos registros das condenações, CT.TLL, n ${ }^{\circ} 19$ (15 de outubro de 1288). O notário de Tarascon, que inquiriu sobre as praticas judiciárias do Templo, procurou, igualmente, saber se o juiz da corte templária redigia ou não suas sentenças, CT.TLL, $n^{\circ} .20$.

${ }^{33}$ Quam curiam tenet et tenuerunt toto dicto tempore, prout et sicut dictum est, super predictis et aliis que infra sequentur et super consulibus confirmandis cum juramento quod prestant et prestiterunt (... in) manibus preceptorum dicte milicie, qui preceptores fuerunt dicto tempore in dicto castro Montisfrini, seu in manibus illorum qui eorumdem preceptorem loca tenuerunt, et in criminalibus inquirendi et puniendi et condempnendi et absolvendi et super eisdem penas inpositas seu sentencias latas exequendi et elevandi et exigendi et transigendi (...) super eisdem sive super predictis criminibus quibuscumque processum fuerit par accusationem alicujus seu per denunciationem seu per modum exceptionis vel ex [officio] curie dicte domus milicie vel quocumque alio modo, CTGard, $\mathrm{n}^{\circ} .139$ (8 de abril de 1293).

${ }^{34}$ Inquisitio facta ex officio curie de Lanciacis et ad denuntiationem Johannis Aymes de Carpentorate (...) contra Pontium de Croso, de Tharascone, super eo videlicet quod dictus Johannes Aimes, dicte curie conquerendo, denuntiavit quod..., CT.TLL, ${ }^{\circ} .18$ (27 de abril de 1288). Cf. também: CT.TLL, nº 25 (29 de outubro de 1299); ou CTGard, $\mathrm{n}^{\circ} .100$ (setembro-dezembro de 1250).

${ }^{35}$ CTGard, $n^{\circ}$. 100; CT.TLL, $n^{\circ} .18$.

${ }^{36}$ CT.TLL, n ${ }^{\circ} .18$ (27 de abril de 1288): Requisitus si per dictum Pontium super contentione habita inter ipsum et dictum Pontium fuerit in aliquo inculpatus seu contra ipsum fuerit per ipsam curiam requisitum et hoc sub pena X. libr., quam penam solvere promissit totiens quotiens contra voluntatem curie predicte in predictis veniret, obligando se et omnia bona sua, promisit insuper sub pena predicta quod non removebit de bajulia Guillelmi Barrali animalia qui ibi habet, sine licencia curie.

${ }^{37}$ CT.TLL, $\mathrm{n}^{\circ \mathrm{s}} .18$ (27 de abril de 1288) e 25 (29 de outubro de 1299); CTGard, $\mathrm{n}^{\circ \text { s }} .119$ (15 de março de 1279) e 126 ( 16 de maio -5 de agosto de1295).

${ }^{38}$ Em 1250, em um caso de rixa em Montfrin, Guilherme Montauros adianta que os testemunhos reunidos contra ele pela corte deviam o ser realizados em sua presença e reclamava a legitima defesa, distinguindo duas etapas da briga: se ele desferiu golpes de bastão, além de ter sacado uma faca, era para responder à agressão de seu adversário. Após o prazo de oito dias, Guilherme de Montauros, que forneceu três fiadores, se apresentou com três testemunhas favoráveis. Ele foi incriminado, mas o respeito ao procedimento lhe valeu uma atenuação da multa. CTGard, $n^{\circ} .100$ (setembro-dezembro de 1250).

${ }^{39}$ Et quod dicta domus sive preceptor prenominatus (...) habeat in dicta villa et pertinenciis ejusdem ville merum et mixtum imperium et plenam jurisditionem, contensiosam seu voluntariam vel uti penas sanguinis, furtorum, effractorum, raptorum, injuriarum, raptus virginum et generaliter omnium criminum quecumque sint vel esse possint. Et quod dicta domus (...) audiat (...) per se vel per bajulos suos, de cetero causas et lites tam criminales quam civiles, peccunarias, magnas et modicas, et generaliter omnes causas cujuscumque generis moverentur in dicta villa, et ita omnis juriditio ex integro, sicut supra dictum est, remaneat et pertineat ad dictam domum Templi sine contradictione et questione aliqua consulum vel hominum ville de Lanciaco, CT.TLL, $n^{\circ} .8$ (13 de março de 1237).

${ }^{40}$ Ver, em comparação, os processos conservados pela corte temporal dos papas no século XIV (CHIFFOLEAU, 1984, p. 161-166).

${ }^{41}$ A effusio sanguinis era frequentemente considerada na medida em que constituía um critério determinante da gravidade da pena, CT.TLL, $\mathrm{n}^{\circ \mathrm{s}}$. 16 e 28 .

${ }_{42}$ A respeito das injúrias e o atentado a honra.

${ }^{43}$ CTGard, $\mathrm{n}^{\circ} .131$ (agosto de 1287).

${ }^{44}$ CTGard, ${ }^{\circ}$. 119 (19 - 22 setembro de 1278), 120 (5 de outubro de 1278), 125 ter (3 - 18 fevereiro de 1292/3), 141 (30 de maio - 7 de dezembro de 1294).

${ }^{45}$ CTGard, $\mathrm{n}^{\circ} .139$ (abril-maio de 1293).

${ }^{46}$ Em 1266, por exemplo, um acordo de associação entre o Templo e a abadia beneditina de Psalmodi para a criação de uma nova vila em Camargue previa a partilha dos rendimentos da justiça civil, mas reservava a justiça de sangue aos irmãos guerreiros, arquivos departamentais de Gard, H 888 (3 de março de 1266).

${ }^{47}$ Tarifas das penas de 14 de março de 1235.

R. Fac. Dir. UFG, v. 39, n.1, p. 53 - 75, jan. / jun. 2015 
${ }^{48}$ Segundo ADBdR, 56 H 5223 (Jalès, 1283), 56 H 4956 (Saint-Maurice, 1324) e A.-R. Carcenac [1994, p. 202, (1278)].

${ }^{49}$ Detenção para espera de julgamento: CT.TLL, $\mathrm{n}^{\circ}$. 12, 20; CTGard, $\mathrm{n}^{\circ}$. 119. Um suspeito foi aprisionado durante três semanas no manso do Templo em Trébon a ponto de se encontrar muito enfraquecido, CT.TLL, $\mathrm{n}^{\circ}$. 25 (29 de outubro de 1299).

${ }^{50}$ CT.TLL, $\mathrm{n}^{\circ} .20$ (3 - 11 de janeiro de 1289/90). Em Manosque, os condenados que deviam 60 soldos ou mais e eram insolventes tinham a mão amputada. (REYNAUD, 1981, 172-173).

${ }^{51}$ A indulgência da justiça hospitalária, em Canabières, justificada notadamente pela pobreza dos acusados, foi igualmente destacada (CHARNAY, 1990, p. 486 e 493).

${ }_{52}$ CTGard, $\mathrm{n}^{\mathrm{os}}$. 125 ter (18 de fevereiro de 1292/3) e 127 (1285).

${ }^{53}$ CT.TLL, $\mathrm{n}^{\circ \mathrm{s}} .14$ (pelourinhos) e 20 (forcas).

${ }^{54}$ Processos verbais de nomeação: CT.TLL, ${ }^{\circ}$. 10 (13 de dezembro de 1259 e 27 de janeiro de 1262/3); CTGard, $n^{\circ} .119$ (21 de março de 1294/5). Esta publicidade dos gestos e das palavras caracterizava também o "teatro judiciário" tal como era oferecido pelos oficiais pontificais em Comtat no século XIV (CHIFFOLEAU, 1984, p. 70-73).

${ }^{55}$ CT.TLL, ${ }^{\text {os }} .11$ (23 de abril de 1262), 14 (9 de março de 1265/6), 16 (16 de março de 1275/6) e 24 (5 de março de 1298/9).

${ }^{56}$ CT.TLL, $n^{\circ s} .11,16,24,25,28$. A ausência de provas conduzia à absolvição, CTGard, $n^{\circ} .126$ (16 de maio - 5 de agosto de 1295).

${ }^{57}$ Sobre o arbitrium ver: J.-M. Carbasse (2000, p. 203-214) e também J. Chiffoleau (2006, p. 448-450).

${ }^{58}$ CT.TLL, ${ }^{\circ \mathrm{s}}$. 11, 24, 28.

${ }^{59}$ CTGard, $\mathrm{n}^{\circ} .119$ (15 de março - 22 de setembro de 1279 e 19 - 22 de setembro de 1278), 120 (outubro de 1278), 125 ter (fevereiro de 1284) e 141 (maio de 1297 e maio de 1294). A composição conduzia a uma resolução de natureza financeira e permitia ao senhor obter uma compensação pela perda de uma multa (MAC CAUGHAN, 2005, p. 30).

${ }^{60}$ CT.TLL, n ${ }^{\circ} .16$ (16 de março de 1275/6).

${ }^{61}$ A inquirição pontifical de 1338 sobre o Hospital não permite redigir estatísticas verdadeiras: os rendimentos e, sobretudo, os custos da justiça estão longe de serem sistematicamente repertoriados. Além disso, as multas eram, às vezes, contabilizadas entre os direitos de ban, as leydes e mesmo as lods e as trézains (BEAUCAGE, 1982).

${ }_{62} \mathrm{O}$ inquérito de 1338 é pouco prolixo sobre este ponto e apenas fornece informações esparsas. Sabe-se, por exemplo, que a antiga comendadoria do Templo de Arles dispensava três medidas de trigo (saumées), 12 libras, 13 soldos e 4 denários para a manutenção de um advogado e de um procurador. Aquela de Trinquetaille dispensava 26 libras e 5 soldos para a manutenção de dois advogados encarregados de defenderem seus direitos e 2 libras para um procurador (BEAUCAGE, 1982, p. 623, 629 e 613-614).

${ }^{63}$ Em comparação, a justiça dos pequenos senhorios hospitalários da Alta Provença rendiam somente entre 10 soldos e 2 libras (FIXOT, 1995, 150-154).

64 Ex adverso respondebant predicti consules (...) dictam universitatem longissimo tempori obtinuisse consulatum in dicta villa et consules qui pro tempore erant in dicta villa audiebant aliquando causas et diffiniebant, CT.TLL, $\mathrm{n}^{\circ} .08$ (13 de março de 1237).

${ }^{65}$ Com a notável exceção da jurisdição manosquina, nenhum estatuto proveniente do senhorio de uma ordem militar foi conservado para a Provença. Mas os documentos procedimentais se referiam a ele (CT.TLL, $n^{\circ} .24$; CTGard, $n^{\circ}$. 123), quando não questionavam sobre o clamor (CT.TLL, $n^{\circ}$. 16). Em compensação, numerosas sauvetés ou jurisdições rurais dotadas de imunidades, fundadas pelos hospitalários em Comminges foram dotadas com cartas de direitos e isenções contendo regras de direito privado e, sobretudo, de direito penal (OURLIAC, 1979, p. 69-71).

${ }^{66} \mathrm{Em}$ 1267, a corte de Lansac lançou um inquérito de ofício a propósito do roubo das forcas patibulares, desmontadas e escondidas por um habitante, CT.TLL, ${ }^{\circ} .14$ (30 de junho de 1267).

${ }^{67} \mathrm{O}$ tema da ascendência da justiça real é bem balizado. Para a Provença, ver os artigos de F. Mazel (2005, p. 343-370) - que nuança o irresistível avanço da justiça soberana - L. Verdon (2005, p. 371-382) e T. Pécout (2005, p. 383-402).

${ }^{68}$ Este recrudescimento dos conflitos a partir de 1260 caracteriza também as relações da aristocracia com a justiça soberana (MAZEL, 2005, 344-353).

${ }^{69}$ Em 1260, quando as duas cortes disputaram o julgamento de uma agressão contra um cisterciense, o debate consistiu em saber se a dita agressão ocorrera em um caminho público, CT.TLL, ${ }^{\circ}$. 12 (23 de janeiro - 10 de fevereiro de 1265/6) e 13 (10 de fevereiro de 1265/6). Sobre os casos reais, ver: G. Giordanengo (2005, p. 119).

${ }^{70}$ CT.TLL, $\mathrm{n}^{\circ} .22$ (22 de janeiro de 1295/6). Trata-se de uma reivindicação clássica ligada aos casos reais. Ver, por exemplo: L. Verdon (2005, p. 374-377).

${ }^{71}$ CT.TLL, ${ }^{\circ} .12$ (23 de janeiro - 10 de fevereiro de 1265/6). 
${ }^{72}$ Em 1296, templários e oficiais condais procederam a uma nova inspeção do território de Lansac, cujos limites materializados por elevações de terra tinham sido levados pelo Rhône, CT.TLL, $\mathrm{n}^{\circ}$. 22 (21 de janeiro de 1295/6).

${ }^{73}$ CTGard, $\mathrm{n}^{\circ} .132$ (20-21 de maio de 1288) e 139 (abril-maio de 1293).

${ }^{74} \mathrm{CGH}, \mathrm{n}^{\circ} .3416$ (31 de março de1271) e $3418\left(1^{\circ}\right.$ de abril de 1271$)$.

${ }^{75}$ CTGard, ${ }^{\circ} .123$ (2 de maio de 1279 - 17 de setembro de 1279) e 133 (4 de setembro de 1288) e M. Hébert (1987, p.147-148).

${ }^{76}$ Em torno de Lansac, em várias ocasiões, o comendador de Arles reclamou diante a justiça real que ela lhe remetesse homens que foram subtraídos pela fuga da justiça do Templo, CT.TLL, $\mathrm{n}^{\circ}$. 27. Em Montfrin, ocorreu ainda que homens da ordem fugissem para se colocar sob a proteção da jurisdição do rei da França, CTGard, ${ }^{\circ}$. 139 ( 8 de abril - 27 de maio de 1293).

${ }^{77} \mathrm{CGH}, \mathrm{n}^{\circ} .3394$ (junho de 1270). A prevenção que permitia à corte real substituir o senhor negligente foi utilizada igualmente pelos (GIORDANENGO, 2005, p. 121).

${ }^{78}$ CGH, $n^{\circ} .4773$ (4 de dezembro de 1307) e Isnard (1894, p. 156-158, n ${ }^{\circ}$ XLIX). Cf. Mac Caughan (2005, p. 3032).

${ }^{79}$ CT.TLL, ${ }^{\circ} .15$ (20 de fevereiro de 1272/3), 16 (27 de abril de 1276) e 19 (15 de outubro de 1288).

${ }^{80}$ Templários: Bertran Monnier (CT.TLL, $\mathrm{n}^{\circ}$. 20), Joan de Monte Regali (CT.TLL, $\mathrm{n}^{\circ}$. 23); estatuto indeterminado: Uc de Saint-Jean (CT.TLL, $\mathrm{n}^{\circ}$. 21). Sobre o papel destes procuradores, laicos ou irmãos, na comendadoria do Templo de Paris no século XIV, ver: G. Étienne (1987, p.323-324).

${ }^{81}$ Para conhecer os detalhes: Carraz (2005, p. 385-387).

${ }^{82}$ Entre 1286 e 1300, confrontados às exações dos habitantes de Antibes e de Villeneuve, antes de depor uma reclamação junto ao bispo de Grasse, os templários de Biot preferiram acionar os juízes de Grasse e Nice e, em seguida, apelar à corte de Aix (DURBEC, 1935, 187-194).

${ }^{83}$ Sobre a sobrevivência dos modos de resolução privados, ver: Carbasse (2000, p. 157-162).

${ }^{84}$ Sobre a Igreja e o "horror do sangue", ver: Carbasse (2000, p. 153).

${ }^{85}$ Hec sunt condempnationes late per me, Bertrandum de Luperiis, juris civilis proffessorem, judicem Lanciaci et de Trebontio, quas proffero in hiis scriptis more majorum in domo milicie Templi civitatis Arelatis sita appud Lanciacum, in qua curiam et diem assiziarum tenere usutatum, Deum habendo pro occulis, Dei nomine primitus invocato, in nomine Patris et Filii et Spiritus Sancti amen, Sacrosanctis Dei Evangeliis coram me positis, non declinans plus ad dextram quam ad sinistram, set puram equitatem et justiciam inthuens ad condempnandem homines infrascriptos..., CT.TLL, $\mathrm{n}^{\circ} .28$ (24 de agosto de 1307). Em Montfrin também: CTGard, $\mathrm{n}^{\circ}$. 125 ter (18 de fevereiro de 1292/3). Sobre a presença dos santos Evangelhos quando da sentença, ver: Martine Charageat (2007. p. 317-342) e sobre a expressão "semper habere Deum prae oculis", relativa à consciência do juiz e a interdependência entre foro interno e foro externo, ver: Chiffoleau (2006, p. 454-456 e 412-418).

${ }^{86}$ CT.TLL, $\mathrm{n}^{\circ} .24$ (5 de março de 1298/9): ...et ipsos ad pecandum et fornicandum, tam viliter solicitavit, promovit et provocavit, et quia fuit causa tocius peccati et tocius libidonos supradictorum...; $\mathrm{n}^{\circ} .16$ (27 de abril de 1276): et cum talia sint digna maxima ultione et correctione in dominos suos ita comittere et peccare...; $\mathrm{n}^{\circ}$. 25 (fuga da prisão, 29 de outubro de 1299): Stinctu dyabolico ductus et immemor sue salutis...; $\mathrm{n}^{\circ} .28$ (roubo de um carneiro, 24 de agosto 1307).

${ }^{87}$ CT.TLL, $n^{\circ} .24$ (5 de março de 1298/9).

${ }^{88}$ CT.TLL, ${ }^{\circ \mathrm{s}}$. 11 e 28. Cf. C. Vachon (1989).

89 "L'institution judiciaire est investie par la prédication, l'ordre civique supplanté par l'ordre moral" Lavoie (1987, p. 15-16) e Mac Caughan (2005, p. 241-242). No senhorio hospitalário de Saint-Christol, é somente após o fim da Idade Média que os estatutos retomam a blasfêmia, ADBdR, 56 H 4872.

Artigo recebido em 15 de março de 2015 e aceito em 30 de junho de 2015 